\section{STILL-LIFES OF THE "SMALL DUTCH" AS PRIMARY SOURCES OF MOTIVES OF THE "GERMAN FLOWERS" IN PORCELAIN}

Olga Shkolna, https://orcid.org/0000-0002-7245-6010 Doctor of Arts, Professor at the Department of Fine Arts, Boris Grinchenko

Kyiv University, Kyiv, Ukraine dushaorchidei@ukr.net
Abstract

The aim of the research is to analyse the sources of inspiration of motives of the "German flowers" ("the Saxon pattern", "the Saxon attire") in the European porcelain and the faience, connected with creative works of thw well-known masters of the "small Dutch". The research methodology includes ontological, historical and chronological methods as well as the method of the art criticism analysis. The ontological method is connected with the presence of a genre of a flower still-life in the paintings of old masters. The second method correlates with the list of names of artists who used to turn to the image of field and garden flowers in the Flemish and Holland fine arts in the XVII-XVIII centures. The method of the art criticism analysis will be used for the analysis of works of leading European manufactories of thin ceramics where the assortment patterns of "the Saxon attire" were largely popular. Scientific novelty is connected with the defining

\section{НАТЮРМОРТИ «МАЛИХ ГОЛЛАНДЦІВ॥ ЯК ПЕРШОДЖЕРЕЛА МОТИВІВ «НІМЕЦЬКІ КВІТИ» У ФАРФОРІ}

\section{Ольга Школьна,}

https://orcid.org/0000-0002-7245-6010

доктор мистецтвознавства,

старший науковий співробітник,

профресор кафедри

образотворчого мистецтва,

Київський університет

імені Бориса Грінченка,

Київ, Україна

dushaorchidei@ukr.net

\section{Анотація}

Мета дослідження - встановити джерела інспірацій мотивів «Німецькі квіти» («Саксонський візерунок», «Саксонський убор») у європейському фарфорі та фаянсі, пов'язані із творчістю відомих «малих голландців» та їх взаємозв'язок з мотивами розписів українського фарфору й фаянсу кін. XVIII сер. XX cт. Методологія дослідження включає сукупність онтологічного, історико-хронологічного та мистецтвознавчого методів аналізу. Перший пов'язаний із побутуванням у живописі старих майстрів жанру квіткового натюрморту. Другий - із переліком імен художників, які зверталися до зображення польових та садових квітів у фламандському та голландському образотворчому мистецтві XVII-XVIII ст. Третій застосовуватиметься для аналізу творів провідних європейських тонкокерамічних мануфактур, в асортименті яких були поширені візерунки «Саксонський убор». Наукова новизна 
of interrelations of the decor of the "German flowers» in the Ukrainian porcelain and faience of the end of the XVIII - the beginnings of the $X X$ centures with the samples of flower still-lifes of the "small Dutch" in the XVI-XVIII ct. Conclusions. Thus, having considered the still lives of the first elements of the "little Dutch" of the XVIII-XVIII centuries and European porcelain and faience products of the XVIII-XX centuries the genetic affinity of their floral motives was established. In particular, the works of leading European centers of "white gold", beginning with Meissen and Berlin, and ending with Ukrainian Korts and Baranivka, evidence this. At the same time, artists of fine ceramic enterprises relied on a bank of drawings and iconography of flowers of "fantasy bouquet" (from different seasons), which included, first of all, motives of "king-flower" (tulip, carnation, daffodil, rose) surrounded by flowers of "royal suite", namely, daisies, cornflowers, poppies, blushes, marigolds, violets, lilies of the valley, peonies, forget-me-nots, wild hips, and more.

\section{Keywords:}

"German flowers", "the Saxon attire", still-lifes of the "small Dutch", the Ukrainian porcelain and faience of the end of the XVIII - the middle of the $X X$ ct. пов'язана із встановленням взаємозв'язку декору «Німецькі квіти» в українському фарфорі-фаянсі кінця XVIII - початку XX ст. із зразками квіткових натюрмортів «малих голландців» XVI-XVIII ст. Висновки. Отже, розглянувши першоелементи натюрмортів «малих голландців» XVII-XVIII ст. та європейських виробів фарфору і фаянсу XVIIIXX ст., встановлено генетичну спорідненість їхніх квіткових мотивів. Зокрема, про це свідчать твори провідних європейських центрів «білого золота», починаючи з Майсену та Берліну, і закінчуючи українськими Корцем і Баранівкою. При цьому художники тонкокерамічних підприємств спиралися на банк малюнків та іконографію квітів «фантазійного букету» (з різних пір року), що включала, насамперед, мотиви «цар-квітки» (тюльпану, гвоздики, нарцису, троянди) в оточенні квітів «царської свити», а саме маргариток, волошок, маків, рум'янку, календули, фіалок, конвалій, півоній, незабудок, шипшини тощо.

\section{Ключові слова:}

мотив «Німецькі квіти», мотив «Саксонський убор», натюрморт, «малі голландці», український фарфор-фаянс кінця XVIII середини XX ст.

Вступ 1 Українська тонка кераміка класичної доби розвитку - кін. XVIII - поч. XX ст. -сьогодні вивчена не достатньо. Потребує досліджень як банк форм і фасонів, так і декор предметів вітчизняних виробництв фарфору-фаянсу. Особливо це питання актуальне у сучасних умовах ринку тонкої кераміки України, в якому майже повністю припинили існування старі фарфоро-фаянсові бренди і поступово починають з'являтися нові, що ще не мають напрацьованої культури формотворення та декорування посуду.

\section{Мета дослідження}

Проаналізувати походження мотивів «Німецькі квіти» («Саксонський убор») у європейському фарфорі та фаянсі, пов'язані з творчістю відомих «малих голландців». Завдання роботи простежити появу квіткових натюрмортів у європейському живописі, охарактеризувати специфіку трансформацій цього жанру в окремих фламандських і голландських майстрів, з'ясувати час розробки подібних мотивів у декоруванні німецького, 
австрійського, чеського, французького, англійського та українського фарфору-фаянсу.

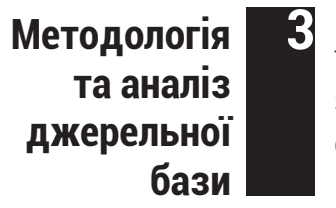

Методологія дослідження базується на онтологічному, історико-хронологічному та мистецтвознавчому методах аналізу. Онтологічний дозволяє розкрити побутування у живописі старих майстрів жанру квіткового натюрморту. За допомогою історико-хронологічного методу вибудовується перелік імен художників, які зверталися до зображення польових і садових квітів в образотворчому мистецтві Нідерландів, а після їх розпаду у першій половині - середині XVII ст., Голландії та Фландрії (терени сучасної Бельгії) впродовж XVII-XVIII ст. Метод мистецтвознавчого аналізу дає змогу здійснити аналіз творів провідних європейських тонкокерамічних мануфактур, у продукції яких були поширені візерунки «Саксонський убор».

Оскільки асортимент творів «білого золота» складає частину сучасної джерельної бази з промислового дизайну (протодизайну), варто розглянути окремі розробки, за якими встановлюються джерела інспірацій тих чи інших варіантів розпису. Одним з найбільш ранніх і, водночас, надзвичайно цікавих з художньої точки зору, є мотив оздоблення, що в європейській літературі отримав сукупну назву «Німецькі квіти» або «Саксонський убор» («Саксонський візерунок»). Про нього писала німецька дослідниця Хела Шандельмайєр (2012) у статті ««алтійське рококо»: фаянс XVIII ст. з країн Балтійського регіону»» в колективній монографії «Виноградовські читання», виданій у Санкт-Петербурзі за підтримки європейської Асоціації друзів кераміки. Дослідниця зазначала, що «найбільш популярним мотивом розпису стали німецькі квіти, створені близько 1735 р. на Майсенській фарфоровій мануфактурі» (с. 118). На їі думку, «мова йде про зображення квітів, виконаних у надто реалістичній манері з виключною ботанічною точністю і, як правило, у різній колористичній гамі. Загалом, це характерно майже для всіх європейських мануфактур» (Шандельмайєр, 2010, с. 118). Але щодо прототипів та джерел інспірацій згадана авторка нічого не розтлумачує.

В іншій статті, розміщеній у цьому ж виданні під назвою «Фарфор, фаянс і майоліка 1830-1940-х рр.», кандидат мистецтвознавства Анна Тарханова (2010) пише наступне: «Як відомо, букети з троянд і дрібних квітів активно використовувались у розписі севрських тарілок 1755-1760 рр.» (с. 320). Подібні мотиви ввійшли в широкий ужиток на Імператорському фарфоровому заводі Росії, де впродовж 1750 - 1760-х рр., фактично відразу після відкриття виробництва, виконувалися аналогічні мистецькі твори (Тарханова, 2010, с. 320). 
Проте, замість довільної, інколи асиметричної, навіть дещо розлогої манери з природними вигинами стебел і пагонів, яку ми спостерігаємо у німецькому фарфорі, продукція Севру здебільшого культивувала пуп'янкоподібні розани заокругленої всередину форми. Останні найчастіше з'єднувалися у потрійні «грона», обвивалися стрічками та тоненькими гірляндами з дрібніших квітів, котрі утворювали ритмічний «танцювальний» візерунок кіл або овалів з вінками. При цьому стрічки інколи викладалися в орнаментальні повторення бантів іперетворювали сприйняття таких тарілок на речі для святкових чи весільних тортів. Наближеними до французьких прообразів виглядали й їхні репліки на російському фарфорі та фаянсі.

Результати
дослідження
На противагу французькому і російському, український фарфор класичної доби розвитку (від своєї появи до революційних змагань початку XX ст.) більшою мірою всотував культуру декору країн німецького світу. Це може бути пов'язаним із тим фактом, що власники перших мануфактур тонкої кераміки, зокрема, Прот Потоцький та Юзеф Чарторийський заснували свої підприємства у Чуднові та Корці на початку 1780-х рр., невдовзі після завершення доби Августа III. Так історично склалося, що цей король Речі Посполитої, до земель якої тоді входили землі Волині, одночасно був австрійським курфюрстом. Відповідно, мистецькі орієнтири тогочасної аристократичної верхівки, яка була замовником найякісніших взірців українського «білого золота», оберталися довкола естетичних орієнтирів короля та придворного нобілітету.

Потім матір'ю останнього польського короля Станіслава ॥ Понятовського (1764-1795), як вказує інший німецький дослідник Егон Кляйн (2010), була княгиня Констанція Чарторийська (с. 132). Тобто Юзеф Чарторийський був ї̈ близьким родичем. Прот Потоцький був компаньйоном останнього, адже йому, крім Чуднова, де 1783 р. вже діяло фарфорово-фаянсове виробництво, належало близько 5-ї частини акцій підприємства у Корці. Фабрика тут була започаткована 1783 р. і введена в експлуатацію 1784 р., цебто до третього переділу Польщі, коли західноукраїнські землі частково потрапили під юридичне підпорядкування французького імператора Наполеона Бонапарта (Варшавське герцогство, 1805-1813/1815 рр.), й, надалі, Росії.

Враховуючи, що до середини XVIII ст. посуд провідного німецького виробництва фарфору в Майсені призначався, насамперед, для монархів та їхнього найближчого оточення, тільки з другої половини ст. високоякісна тонка кераміка почала демократизуватися. Так, європейський флоральний декор став «стандартизуватися». На зміну раннім майсенським квітковим орнаментам переважно синього кольору «Цибульчастий де- 
кор» (контурний рисунок з пізнішим пензлевим доведенням, у вигляді поєднання мотивів граната, бамбука, хризантеми й персика) та «Сухоцвіт» (лінеарний рисунок), що орієнтувались на східну моду в оздобленні тонкої кераміки, прийшли гедоністичні поліхромні композиції європеїзованих «квітучих букетів квітів» (Тарханова, 2012, с. 148-153).

Замість орієнтації на пресловутих «Квітів та птахів» з китайського мистецтва, мотив «Німецькі квіти» передував появі більш вихолощеного «Манеру». Останній з'явився близько 1790-х рр., у ньому живопис розкидних флореальних мотивів, що нібито жваво рухалися, перетворювався на мертву натуру. По суті, «Саксонський убор» підготував появу в Англії на межі кін. XVIII - на поч. XIX ст. візерунку «Ботанічних квітів», що дав поштовх розвитку відомих мотивів кшталту «Флора Даніка», «Флора Русіка» тощо. Однак, власне «Манер», що відбрунькувався від «Німецьких квітів», упродовж півстоліття намагався позбутися саме цього ботанічного ефекту і відійшов від природного атласу квітів до стилізованого у певній манері гербарію (Тарханова, 2012, с. 151-153). Це й дало початок його назві.

Тобто, між 1735 і 1790-ми рр. в європейському фарфорі та фаянсі мотив «Саксонського убору» був провідним, хоча паралельно продовжував існувати візерунок «Індіанські квіти» та близько 1740-х рр. поширився декор «Ксилографічні квіти», позначений рисами зів'ялості (Лехельт, 2011, с. 73). З-поміж інших «Німецькі квіти» стали найбільш «живими» й знаходили розуміння серед поціновувачів садів, що супроводжувалось розведенням рідкісних різновидів флори, а також натуралістів, біологів, селекціонерів рослин тощо. Цебто живописна вільна манера, що віртуозно виконувалася вручну, часто за один підхід, не відриваючи руки (мустер), в цей період стає найбільш затребуваною.

Виразними і яскравими за кольором «Німецькі квіти» були впродовж доби рококо - 1740-х - 1750-х рр., коли в Україні ще не розпочалося виготовлення фарфору. Тотальна мода на це оздоблення сервізів та окремих речей спостерігалася між 1750-ми та 1760-ми роками. В середині - другій половині XVIII ст. живописний розпис часто поєднувався з рельєфним декором. Зокрема, з візерунками «Старий Озьє» (кошикова плетінка з вербової лози, - мотив, винайдений 1730 р.), «Новий Озьє» (поширений з 1730-х рр. мотив вербової лози, поєднаний з характерною для рококо хвилястою лінією), «Лебединий сервіз» (1737-1741 рр., поєднаний з пластичними мотивами лебедів), «Старий Бранденштайн» (з 1738 р. для замовника Ф. А. Бранденштайна виконувався у вигляді плетінки по борту та прямих смуг від борту до центру предмету, часто доповнювався у проміжках розписом у стилі «шинуазрі»), «Опуклі квіти Гоцовського» (для німецького купця Гоцовського - візерунок 
дрібних квітів, що розпустилися), «Марсель» (1739-1743 рр., гірлянди квітів, що розпустилися та шість рогів достатку, запозичених з мотивів руанського фаянсу), «Рельєфний убор Дюлонг» (на замовлення французького купця Дюлонга, дрібний рельєфний квітковий декор, відомий з 1743 р.).

Крім інших, в пластичних оздобленнях Майсену був поширений «Рельєф Брюля» (1742-1746рр., елементи плетінки з рослинними завитками, що чергуються з ділянками рослинного поліхромного розпису), «Новий Бранденштайн» (мотив вербової лози з s-подібними смугами, з 1744 р.). Пізніше окремі розробки пластичного декору цього виробництва почали відтворювати на інших німецьких та австрійських мануфактурах. Так, приміром, близько 1790 р. візерунок «Старий Озьє» спостерігається у продукції Віденської фарфорової мануфактури. В сучасному асортименті даного виробництва він має назву «Бідермайєр» (хоча стиль бідермайєр побутував пізніше, ніж з'явився даний мотив - із 1815 по 1848/1850-ті рр.) (Васильева, 2017).

До 1780-х рр. поступово «кольоровий градус» у тонкокерамічних виробах почав спадати, хоча викінчений тонкий і бездоганний пензлевий розпис лишався в моді. Наприкінці XVIII ст. поліхромний соковитий декор поступається монохромному розпису за допомогою однієї-двох фарб у синьо-блакитних тонах або у сіро-коричневій гамі гризайлю. Цей «тон» німці успадкували від французького Севру доби Марколіні, коли поширилася мода на строгі античні естетичні ідеали.

Прообразами декору «Німецькі квіти» варто вважати натюрморти з рослинними мотивами у творчості «малих голландців». Першим таким твором стала картина Яна Брейгеля Старшого «Квіти у дерев'яному вазоні» (1606-1607рр.), замовлена Альбрехтом VII Австрійським (рис. 4.1, а). Відомо, що художник задля натуралістичності зображення робив замальовки у змішаній техніці туші з аквареллю у Брюссельському ботанічному саду, для чого спеціально приїжджав з Антверпену. Для нього було важливо мати можливість робити замальовки квітів у різних ракурсах зблизька та ретельно їх розглянути при різному освітленні.

Ян Брейгель Старший залишив значну кількість квіткових натюрмортів та етюдів до них. Його майстерність перейняв син художника, також відомий митець Ян Брейгель Молодший, у творчості якого квіти з крихітних і тендітних створінь перетворились на важливі «персони» першого плану, набули ознак «портретності». Таким, приміром, є натюрморт останнього «Квіти у скляній вазі», виконаний близько другої третини XVII ст. (рис. 4.1., в). В цій роботі художник знайшов для фарфору хрестоматійне надалі поєднання чотирьох цар-квітів: гвоздики, троянди, нарциса й тюльпана в оточенні незабудок, дзво- 
ників, волошок та інших рослин, які у природі не зацвітають одночасно. Такий «фантазійний» принцип і ліг в основу появи мотиву «Німецькі квіти» на «білому золоті». Однак обидва Брейгелі (рис. 4.1., б) часто вводили в свої полотна п'яту цар-квітку, а саме ірис, який в ансамблях композицій «саксонський убор» надалі майже не прижився.

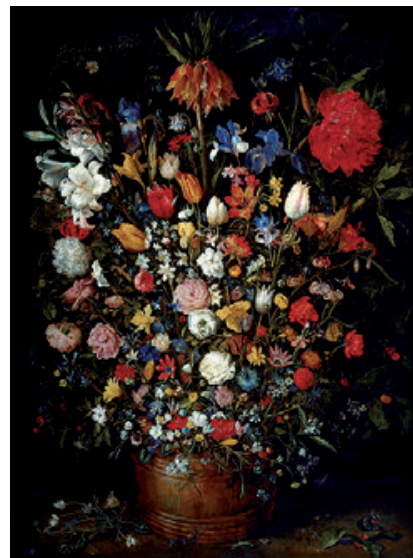

a

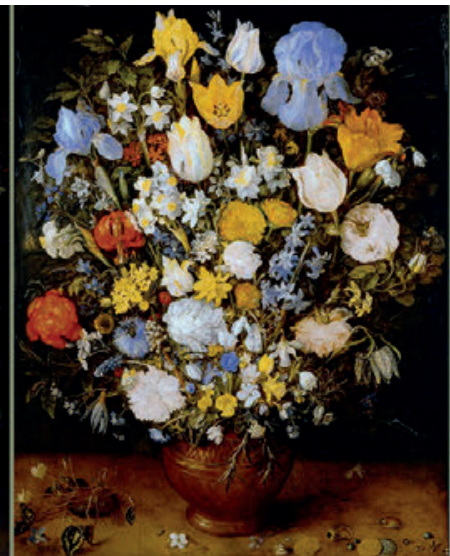

$\sigma$

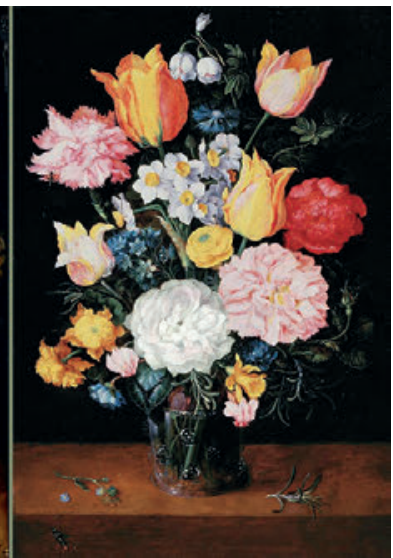

$B$

Рис. 4. 1. Натюрморти Яна Брейгеля старшого $(a$, б) та Яна Брейгеля Молодшого (В).

Fig. 4.1. Still lifes of Jan Brueghel I $(a, 6)$ and Jan Brueghel Yanger (B).

Прикладом для Яна Брейгеля Молодшого (Пекельного) також був фламандський художник золотого періоду розквіту нідерландського мистецтва Амброзіус Боссхарт Старший. Його цікавила точність зображення й гармонійне поєднання соковитих кольорів квітів у композиції. Наступним видатним митцем означеного жанру став голландець Ганс Болоньєр (Болонгієр, Болонжер). Після 1623 р. цей художник став членом Харлемської гільдії Св. Луки, яка спеціалізувалась на написанні квіткових натюрмортів. У своїх роботах другої третини XVII ст. він намагався «градуювати» колір пелюсток тюльпанів та інших квітів, надавав їм ознак різного ступеню розкриття голівки, виявляв певний «характер» кожної квіткової «моделі» (рис. 4.2).

Проте, від гедоністичних творів своїх товаришів по цеху Яна Брейгеля Старшого (Оксамитового) та Яна Брейгеля Молодшого, його твори відрізняються меншим хроматизмом, їх колорит приглушений, наближений до тонового. Винайдення характерного поєднання окремих квітів тюльпана згвоздикою, трояндою та нарцисом, що пізніше набуло ознак візерунку «Німецьких квітів», варто пов'язувати також із творчістю Ганса Болоньєра. 


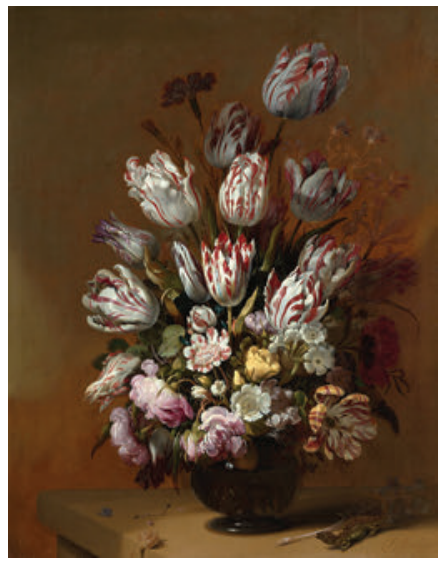

Рис. 4.2. Ганс Болоньєр. Квітковий натюрморт. 1639 p.

Fig. 4.2. Hans Boloner. A flower still-life. 1639

Загалом, слід відзначити, що сам вибір мотивів залежав від краси та рідкісності квітів. Голландія, що була відома своїми дивовижними тюльпанами - це історична область, що включає 2 провінції на заході Нідерландів. Проте у XVII ст., як і сьогодні, в багатьох європейських країнах назву «Голландія» ототожнювали з усією країною. «Малими» голландців (нідерландців) називали у разі, якщо вони займалися «малими» жанрами, цебто «тихим життям», а не великими історичними, міфологічними або алегоричними сценами.

Велика вага у добу бароко надавалася тюльпанам, які вважалися майже екзотичною рослиною в інших країнах Європи. Серед «малих голландців», що зверталися до цього жанру в XVII ст., варто відзначити, крім Амброзіуса Боссхарта Старшого, Якоба (Жака) де Гейна Молодшого, Яна Баптиста ван Форненбурга, Ваутерса Восмара. В їхній творчості, яка підготувала розвиток квіткового натюрморту фламандських і голландських митців XVIII ст., склалися основні «іконографічні ізводи» флоральних мотивів того часу. Зокрема, поєднання в букетах композиції з тюльпанів, нарцисів, троянд, фізаліса з фарфоровими вазами.

Накриті столи, кухонний натюрморт, сніданки з тюльпанами, трояндами, гладіолусами, гіацинтами, гвоздиками, лілеями, ірисами конваліями, незабудками, фіалками, маргаритками, календулою, ружею тощо поступово стали ознакою гарного стилю в оселях істеблішменту сусідніх європейських країн. Одним з кращих майстрів жанру «тихе життя», як його називали, був нідерландець Ян Девідс де Хем, в творчості якого натюрморт з квітами набув барокових ознак (рис. 4.3). Надалі тюльпани та їх зображення почали цікавити мешканців Німеччини, Англії й Франції, які вчилися у «малих голландців», у зв'язку з чим популяризація подібних мотивів отримала нечуваного до того розмаху.

До кінця XVII - початку XVIII ст., часу, коли був винайдений європейський фарфор, квітковий натюрморт останніх, розтиражований у Європі, набув значного поширення. Наприкінці XVII ст. 
Деміург: ідеї, технології, перспективи дизайну 2019 Том 2 № 2 Demiurge: ideas, technologies, perspectives of design 2019 Vol. 2 No 2

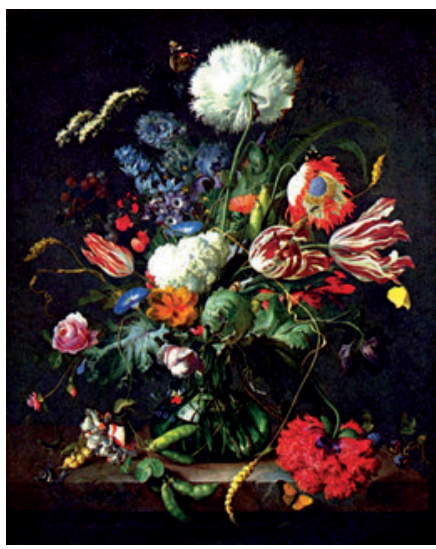

Рис. 4.3. Ян Девідс де Хем. Ваза з квітами. Бл. 1645 р.

Fig. 4.3. Jan Devids de Ham. The Vase with the flowers. Apprx. 1645.

до цього жанру звернувся німецький художник Якоб Моррель, учень Яна Девідса де Хема, який надав реалістичним голландським мотивам більшої романтичності за рахунок складних вигинів пелюсток своїх бездоганних голівок тюльпанів. У добу розвинутого бароко квіткові натюрморти фламандських художників отримали деяку перевантаженість деталями, «іконність», оскільки їх почали виконувати «клеймами» за різними порами року. Таким, приміром, є твір Пітера Кастельса III, який жив у XVIII ст., що представив «Букети квітів на 12 місяців».

Майже синхронно з останнім подібні творчі спостереження вів і англійський художник Генрі Флетчер. Його сюїта ваз з квітами, написана впродовж 1730 р., уособлює 12 місяців (зберігається в Ермітажі). Але слід відзначити, що манера англійця більш суха, ксилографічна, позбавлена тієї соковитості (рис. 4.4), що була притаманна творчості голландських, фламандських і німецьких митців. Десь з цього часу розквіт квіткового натюрморту «малих голландців» згасає.

Власне мотиви польових квітів, похідні від німецько-австрійських аналогів, впродовж кінця XVIII - початку XIX ст. пошири-

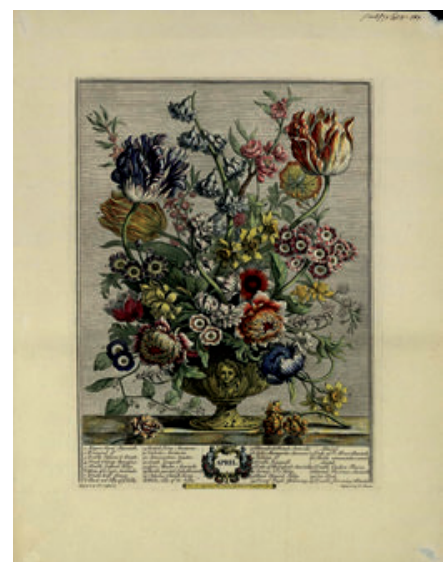

Рис. 4.4. Генрі Флетчер. Один з 12 натюрмортів, написаних між 1730 р. Квітень.

Fig. 4.4. Henry Fletcher. One of 12 still-lifes written to 1730 April. 
лись в богемському фарфорі Чехії, яка входила, як і Західна Україна, до складу Австрійської імперії. На наших землях естетичні уподобання Майсенської фарфорової мануфактури (рис. 4.5), Королівської фарфорової мануфактури в Берліні та Віденської фарфорової мануфактури також стали мистецькими орієнтирами високого «білого золота». Корець, імовірніше за все, Чуднів (продукція якого, на жаль, поки що не розшукана, але мала бути близькою до корецької), а також Баранівка та Городниця, пізніше Романів та Білотин (Школьна, 2013) сповідували ті ж мистецькі прерогативи у фарфорі та тонкому фаянсі.

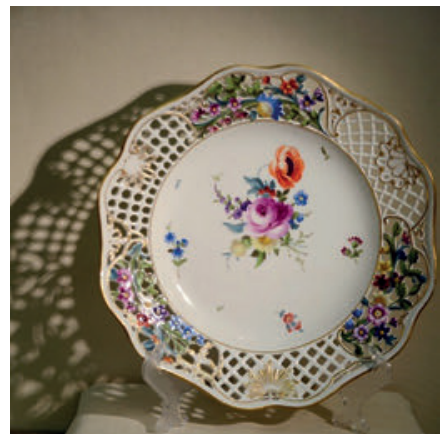

Рис. 4.5. Майсен. Тарілка з розписом «Німецькі квіти» середини XVIII ст.

Fig. 4.5. Meissen. A plate with a list «German flowers» middle XVIII the item.

Окремі зразки мотивів «Німецькі квіти» увітчизняному фарфорі Баранівки та Городниці збереглися до початку XX ст. (решта з перелічених вітчизняних підприємств на той час вже припинила своє існування). Після Другої світової війни на хвилі доступу до секретів старовинних технологій чеського і німецького фарфору та контрибуції, в українському радянському «білому золоті» з'явилися різноманітні мотиви «Німецькі квіти» у декалькоманії. Зокрема, таке явище спостерігалось у продукції, розробленій на Київському експериментальному кераміко-художньому заводі, що на той період часу виконував функції республіканської творчої лабораторії для вітчизняних підприємств галузі (Школьна, 2011).

Поступово з-поміж інших європейських шкіл Чехії (Бернадотте), Угорщини (Херенд), Польщі (Альтвассер-Вальденбург), Франції (Севр), Англії (Мінтон) тощо наші композиції а-ля «Німецькі квіти» набули виразних рис, що споріднюють їх з квітковими натюрмортами «малих голландців», де використовувався рисунок тушшю у комбінації з нанесенням шарів олійного живопису з транспарантними (просвічуваними) фарбами (техніка лесирування). Крім того, на вітчизняну іконографію рослин впливав зв'язок із квітковими мотивами української флори, коли тюльпан писався із сон-трави, яка зростала на наших широтах, троянда, нарцис або гвоздика - з палісадника, й оточувалися дрібними польовими квіточками. Особливий зв'язок 
наших «Саксонських уборів» відчувається між богемською спадщиною колишньої Австрійської імперії, напрацюваннями Королівської фарфорової мануфактури в Берліні (рис. 4.6) та банком малюнків вітчизняних Корця й Баранівки (рис. 4.7).

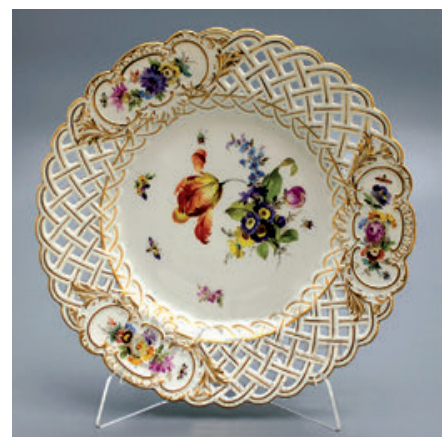

Рис. 4.6. Тарілка з прорізним бортом виробництва Королівської фарфорової мануфактури в Берліні. Кінець XIX ст.

Fig. 4.6. A plate with procarved a board of manufacture of the Royal porcelain manufactory in Berlin. End XIX the item.

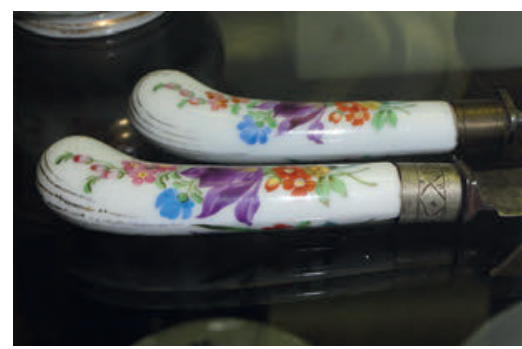

a

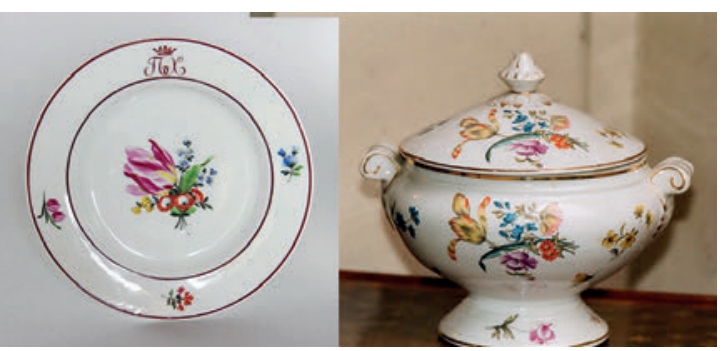

6

Рис. 4.7. Фарфорові вироби Корецької фарфоро-фаянсової мануфактури та Баранівського фарфорового заводу.

Fig. 4.7. Product with motive «German flowers» of the Koretsky farforo-faience manufactory (above) and Baranovsky porcelain factory.

\section{Наукова новизна та практична значимість дослідження}

Спостереження за творами художників північного відродження та бароко в музеях Альбертіна, Стара Пінакотека, Берлінська та Дрезденська картинні галереї, Лувр, Ермітаж тощо та натурні взірці високого фарфору провідних європейських підприємств, які вдалося обстежити впродовж останніх 12-ти років, дозволили припустити істотний зв'язок між візерунками квіткових декорів вітчизняної тонкої кераміки в колі європейських шкіл та натюрмортів старих майстрів. При уважному порівнянні мотивів жанру «тихого життя» окремих художників Нідерландів, Голландії, Фландрії XVII-XVIII ст. та німецьких, австрійських, угорських, чеських, польських, українських, французьких, англійських виробів «білого золота» XVIII-XX ст. стало можливим прослідкувати істотний взаємозв'язок іконографії окремих рослин, елементів побудови композиції, колористичних уподобань, що і стало новизною даного дослідження. 
Висновки 6 Отже, розглянувши першоелементи натюрмортів «малих голландців» XVII-XVIII ст. та європейських виробів фарфору і фаянсу XVIII-XX ст., встановлено генетичну спорідненість їхніх квіткових мотивів. Зокрема, твори провідних європейських центрів «білого золота», починаючи з Майсену та Берліну, і закінчуючи українськими Корцем іБаранівкою, апелювали до живопису Яна Брейгеля Старшого (Квіткового, Оксамитового), Яна Брейгеля Молодшого (Пекельного), Амброзіуса Боссхарта Старшого, Ганса Болоньєра, Яна Девідса де Хема, Якоба Морреля, Пітера Кастельса III. При цьому художники тонкокерамічних підприємств спиралися на банк малюнків та іконографію квітів «фантазійного букету» (з різних пір року), що включала, насамперед, мотиви «цар-квітки» (тюльпану, гвоздики, нарцису, троянди) в оточенні квітів «царської свити», а саме - маргариток, волошок, маків, рум'янку, календули, фіалок, конвалій, півоній, незабудок, шипшини тощо.

\section{Список бібліографічних посилань}

Васильева, О.А. (2017, 10 Ноября). Растительные мотивы в декоре фарфора. Взято из httр:// worontsovpalace.org/rastitelnye-motivy-v-dekore-farfora/.

Кляйн, Э. (2010). Европейские фарфоровые мануфактуры XVIII В. В Е.М. Тарханова \& А. Циффер (Сост.), Виноградовские чтения в Санкт-Петербурге. Фарфор XVIII-XXI вв.: Предприятия. Коллекции. Эксперты, IV международная научно-практическая конференция (с. 127-133). Санкт-Петербург: Издательство Политехнического университета.

Лехельт, К.М.-А., (2011). Искусство декора на мейсенском фарфоре 1710-2010 гг.: Условия и особенности. В Е.М. Тарханова \& А. Циффер (Сост.), Виноградовские чтения в Петербурге. Фарфор Европы и России XVIII веков. Аналогии и различия. Восточные влияния. Мастер-класс, V международная научно-практическая конференция (с. 64-106). Санкт-Петербург: Издательство Политехнического университета.

Тарханова, А. (2010). Русский и зарубежный фарфор и фаянс 1840-1930-х гг. в коллекции Елагиноостровского дворца-музея: Аналогия форм и декора. В Е.М. Тарханова \& А. Циффер (Сост.), Виноградовские чтения в Санкт-Петербурге. Фарфор XVIIIXXI вв.: Предприятия. Коллекции. Эксперты, IV международная научно-практическая конференция. (с. 308-328). Санкт-Петербург: Издательство Политехнического университета.

Тарханова, А. (2012). Таинственный цветок: Флоральные мотивы в декоре фарфора и фаянса XVIII-XX вв. из коллекции ЕОДМ и их графические прототипы. В Е.М. Тарханова \& А. Циффер (Сост.), Виноградовские чтения в Петербурге. Фарфор Еврропы и России XVIII веков. Аналогии и различия. Восточные влияния. Мастер-класс. VI международная научно-практическая конференция (с. 140-167). Санкт-Петербург: Издательство Политехнического университета.

Шандельмайер, X. (2010). Балтийское рококо: фаянс XVIII века из стран Балтийского региона В Е.М. Тарханова \& А. Циффер (Сост.), Виноградовские чтения в Санкт-Петербурге. Фарфор XVIII-XXI вв.: Предприятия. Коллекции. Эксперты, IV международная научно-практическая конференция. (с. 115-126). Санкт-Петербург: Издательство Политехнического университета. 
Школьна, О. (2011). Київський художній фарфор ХХ ст. Київ: День печати.

Школьна, О. (2013). Фарфор-фаянс України. Історія виробництв (середина XVII - початок XXIст.). Таблиці. Реєстр імен провідних майстрів галузі (Т. 2, Ч. 1). Київ: День Печати.

\section{References}

Kliain, E. (2010). Evropeiskie farforovye manufaktury XVIII v. [European porcelain manufactories of the XVIII century]. In E.M. Tarkhanova \& A. Tciffer (Comps.), Vinogradovskie chteniia $v$ SanktPeterburge. Farfor XVIII-XXI vv.: Predpriiatiia. Kollektcii. Eksperty [Vinogradov Readings in St. Petersburg. Porcelain XVIII-XXI centuries: Enterprises. Collections. Experts], IV international scientific-practical conference (pp. 127-133). St. Petersburg: Izdatelstvo Politekhnicheskogo universiteta [in Russian].

Lekhelt, K.M.-A., (2011). Iskusstvo dekora na meisenskom farfore 1710-2010 gg.: Usloviia i osobennosti [The art of decor on Meissen porcelain 1710-2010: Conditions and features]. In E.M. Tarkhanova \& A. Tciffer (Comps.), Vinogradovskie chteniia v Peterburge. Farfor Evropy i Rossii XVIII vekov. Analogii i razlichiia. Vostochnye vliianiia. Master-klass [Vinogradov Readings in St. Petersburg. Porcelain of Europe and Russia of the XVIII centuries. Analogies and differences. Eastern influences. Master class], $V$ international scientific and practical conference (pp. 64-106). St. Petersburg: Izdatelstvo Politekhnicheskogo universiteta [in Russian].

Shandelmaier, Kh. (2010). Baltiiskoe rokoko: faians XVIII veka iz stran Baltiiskogo regiona [Baltic Rococo: faience of the 17th century from the countries of the Baltic region]. In E.M. Tarkhanova \& A. Tciffer (Comps.), Vinogradovskie chteniia v Sankt-Peterburge. Farfor XVIII-XXI vv.: Predpriiatiia. Kollektcii. Eksperty [Vinogradov Readings in St. Petersburg. Porcelain XVIII-XXI centuries: Enterprises. Collections. Experts], IV international scientificpractical conference. (pp. 115-126). St. Petersburg: Izdatelstvo Politekhnicheskogo universiteta [in Russian].

Shkolna, O. (2011). Kyivskyi khudozhnii farfor XX st [Kiev Art Porcelain of the XX century]. Kyiv: Den Pechaty [in Ukrainian].

Shkolna, O. (2013). Farfor-faians Ukrainy. Istoriia vyrobnytstv (seredyna XVII - pochatok XXI st.). Tablytsi. Reiestr imen providnykh maistriv haluzi [Porcelain faience of Ukraine. Production history (middle of the XVII - beginning of the XXI centuries). Tables. Register of the names of leading masters of the industry] (Vol. 2, Pt. 1). Kyiv: Den Pechaty [in Ukrainian].

Tarkhanova, A. (2010). Russkii i zarubezhnyi farfor i faians 1840 - 1930-kh gg. v kollektcii Elaginoostrovskogo dvortca-muzeia: Analogiia form i dekora [Russian and foreign porcelain and faience of the 1840s - 1930s. in the collection of the Yelaginoostrovsky Palace Museum: An analogy of forms and decor]. In E.M. Tarkhanova, \& A. Tciffer (Comps.), Vinogradovskie chteniia v Sankt-Peterburge. Farfor XVIII-XXI vv.: Predpriiatiia. Kollektcii. Eksperty [Vinogradov Readings in St. Petersburg. Porcelain XVIII-XXI centuries: Enterprises. Collections. Experts], IV international scientific-practical conference (pp. 308-328). St. Petersburg: Izdatelstvo Politekhnicheskogo universiteta [in Russian].

Tarkhanova, A. (2012). Tainstvennyi tcvetok: Floralnye motivy $v$ dekore farfora i faiansa XVIIIXX vV. iz kollektcii EODM i ikh graficheskie prototipy [Mysterious flower: Floral motifs in the decoration of porcelain and faience of the XVII - XX centuries. from the EODM collection and their graphic prototypes]. In E.M. Tarkhanova \& A. Tciffer (Comps.), Vinogradovskie chteniia v Peterburge. Farfor Evrropy i Rossii XVIII vekov. Analogii i razlichiia. Vostochnye vliianiia. Master-klass [Vinogradov Readings in St. Petersburg. Porcelain of Europe and Russia of the XVIII centuries. Analogies and differences. Eastern influences. Master Class], VI international scientific and practical conference (pp. 140-167). St. Petersburg: Izdatelstvo Politekhnicheskogo universiteta [in Russian].

Vasileva, O.A. (2017, November 10). Rastitelnye motivy $v$ dekore farfora [Plant motifs in porcelain decor]. Retrieved from http://worontsovpalace.org/rastitelnye-motivy-v-dekore-farfora/ [in Russian]. 